\title{
ECONOMIC ISSUES OF DUCK PRODUCTION: A CASE STUDY FROM HUNGARY
}

\author{
Szilvia Molnár¹ - László Szóllősi² \\ ${ }^{1} \mathrm{PhD}$ Student, University of Debrecen, e-mail: molnar.szilvia@econ.unideb.hu \\ 2associate professor, University of Debrecen, e-mail: szollosi.laszlo@econ.unideb.hu
}

\begin{abstract}
The Hungarian waterfowl sector is characterised by export orientation, as 55-57\% of the revenue comes from exports, so its importance is high in the national economy. The production of slaughter animals in the duck sector has doubled in the last decade. The objective of the study is to examine production parameters, as well as the cost and profit situation of broiler duck production and to reveal the correlations between the factors with a case study through the example of a Hungarian company. The production parameters and cost data of the investigated farm (2014-2016, 96 production cycles) were analysed using descriptive statistical methods, correlation and regression analysis. The results show that the average cost of the duck produced in intensive, closed farming system was between 72.6 and 101.7 eurocent $\mathrm{kg}^{-1}$. The most significant cost items were feed (52-63\%) and chicken cost (14-19\%). The sales price decreased from 112.9 eurocent $\mathrm{kg}^{-1}$ to 98.4 eurocent $\mathrm{kg}^{-1}$ during the examined period, resulting in a profit from -3.3 to 25.7 eurocent $\mathrm{kg}^{-1}$, and overall profitability was decreasing. The study also revealed that there was no correlation between average cost and final bodyweight, while the correlation between average cost and reared period was weak. At the same time, the relationship between average cost and average daily weight gain, mortality, feed conversion ratio was moderate. In addition, the European Production Efficiency Factor (EPEF) can be adapted to the duck sector as strong, positive relationship can be scientifically verified between the indicator and average cost. There is a close correlation between the sold live weight per $m^{2}$ and the amount of feed used per $m^{2}$, as well as between the final bodyweight and the amount of feed used to rear a duck, while the correlation between average cost and the sold live weight per $m^{2}$ is weak.
\end{abstract}

Keywords: broiler duck production, production parameters, cost and profit, correlation and regression analysis (JEL Code: Q13, Q19)

\section{INTRODUCTION}

The duck meat production of the world increased by $153 \%$ from 1.74 million tons to 4.39 million tons between 1993 and 2013. On a world scale, China has a significant role in duck meat production. In $2013,68 \%$ of the total produced amount of duck meat originated from the Asian country, which tripled its production from 982 thousand tons to 2999 thousand tons in the examined period. The European Union (EU-28) provided $11 \%$ of the duck meat production of the world in 2013, as its output increased by $87 \%$ in the examined period (FAO, 2017).

On a world scale, duck meat export increased from 67 thousand tons to 266 thousand tons between 1993 and 2013. In 2013, China was the most significant exporting country, exporting 91 thousand tons of duck meat during the year, which is almost twice as much as the respective amount a decade earlier; therefore, $34 \%$ of all global duck meat export was performed by China. Hungary and France are the second and third biggest exporting countries. These two countries had nearly similar share (14\%) of the global duck meat export in 2013. The duck meat export of Hungary increased from 30 thousand tons to 37 thousand tons $(+27 \%)$ between 2003 and 2013. The French export increased more significantly from 14 thousand tons to 37 thousand tons during this period (+176\%) (FAO, 2017).

According to FAO (2017) data, the duck meat import of the world increased from 81 thousand tons to 187 thousand tons $(+130 \%)$ in the last two decades. Similarly to the export data, China has a significant role in import, too, importing 39 thousand tons of duck meat in 2013, which is nearly $30 \%$ lower than before (56 thousand tons). Germany increased its duck meat import significantly from 19 thousand tons to 32 thousand tons $(+60 \%)$ in the examined period. In addition, Saudi Arabia and France also import a notable amount of duck meat, with the formed increasing its import quantity from 1.5 thousand tons to 18 thousand tons and the latter from 0.8 tons to 13 thousand tons between 2003 and 2013.

The Hungarian poultry sector can be characterised by a high level of self-sufficiency (142\% in 2015) and export orientation (AVEC, 2016). The different subsectors of the poultry sector achieve significant export revenue. $55-57 \%$ of revenue originates from export activities in the case of duck and goose; therefore, these sectors are of significant important from the national economic aspect (Csorbai, 2015). In addition, while the animal population decreased in certain subsectors (turkey), the Hungarian duck population increased from 2.7 million to 4 million between 2003 and 2016 (HCSO, 2017). 
Accordingly, the slaughter duck production also extended significantly (+90\%) from 51.4 thousand tons to 100.8 during the recent years and this increase has been constant since 2008 (Bábáné Demeter, 2017). The proportion of the duck subsector is constantly increasing within waterfowl production and it amounted to around three quarters in 2015. The broiler duck subsector has been dynamically developing and the demand for this product is favourable, which may potentially generate growth, but partially at the expense of the goose subsector (Csorbai, 2015). At the same time, the Polish broiler duck production also started to grow. In 2013, only around 5-7 million ducks were slaughtered in Poland, but Polish producers are expected to be a significant competitor within 1-2 years (Kállay, 2014). The major part of Hungarian slaughter duck production is broiler duck for meat consumption purposes, while fattened duck only has a smaller share. Between 2005 and 2015, the members of the Hungarian Poultry Product Board - which cover around two thirds of the Hungarian duck production - produced $86 \%$ of broiler duck production in Hungary. In the recent years, Cherry Valley was one of the most widespread breeds in the Hungarian broiler duck production (Kozák and Szász, 2016). The breeding activity of Cherry Valley resulted in the production of commercial hybrids whose feed conversion is effective and their viability is also good under normal commercial circumstances. The majority of production costs is represented by feed costs; therefore, the reduction of feed conversion ratio (FCR) has a major impact on the profitability of duck production. In addition, the improvement of the effectivity of feed conversion results in less manure (Rae, 2014).

In accordance with the data published by Molnár and Látits (2016), the Hungarian poultry meat consumption (26.46 $\mathrm{kg}$ per person per year) consists of $20.02 \mathrm{~kg}$ chicken, 0.22 $\mathrm{kg}$ hen, $2.96 \mathrm{~kg}$ turkey, $2.43 \mathrm{~kg}$ duck and $0.84 \mathrm{~kg}$ goose per person per year. This amount of consumed poultry meat mainly originates from Hungarian sources and import only has a moderate share. It can be observed that the extent of Hungarian duck meat consumption is low and significant part of the produced amount is sold on foreign markets. The products of the waterfowl sector, including broiler duck, have been facing a great demand in specific markets of Western Europe, mainly in Germany and France (Bogenfürst, 2008). This observation is also reinforced by Comtrade (2017) data, according to which the main export markets of Hungary were Germany, the Czech Republic, Slovakia, the United Kingdom, Austria, France, Belgium and China in 2016. Around 23\% of all exported duck meat was sold in Germany.

Compared to the seasonal character of goose meat, the consumption of duck meat is more balanced and there is a constant level of demand on the market; therefore, demand and supply are in balance. Duck products are sought after by a wider range of consumers and its consumption is constant throughout the whole year, almost becoming a product of daily consumption and it can be sold during the whole year, with the exception of some shorter cycles. During the recent years, the change of consumer needs resulted in a constant shift of demand from goose to broiler duck; moreover, consumers tend to prefer semi-processed or processed broiler duck instead of whole duck. Accordingly, the quality and combination of processing also change. One decade ago, duck was mainly sold as whole duck, while this share reduced to $40-50 \%$ for today and the consumer demand for convenience products has been constantly growing (Dunn, 2008; Avar, 2015).

The aim of this study is to examine the production parameters and cost and profit relations of broiler duck production, as well as revealing connections between each factor through the example of a Hungarian enterprise as a case study.

\section{MATERIALS AND METHODS}

In order to implement the objectives of this study, primary data collection was performed between 2014 and 2016 in relation to 96 production cycles of a specific plant of an enterprise which plays a significant role in the Hungarian waterfowl production. Therefore, the obtained results refer to the examined plant, but they can be generalised in certain topics. Data collection referred to various production parameters (established population, mortality, amount of feed used, sold amount, etc.) and economic data (detailed cost data, sales price). Using the collected data, physical efficiency indicators were derived in relation to the poultry sector, such as mortality rate (\%) daily bodyweight gain (g per day), final bodyweight ( $\mathrm{kg}$ per duck), feed conversion ratio (FCR) (kg per $\mathrm{kg}$ ), sold live weight per $1 \mathrm{~m}^{2}$ of barn $\left(\mathrm{kg}\right.$ per $\left.\mathrm{m}^{2}\right)$ and European Production Efficiency Factor (EPEF). Descriptive statistics (mean, standard deviation, relative standard deviation, minimum, maximum, frequency) were performed during the processing of both primary data and derived indexes. The derived indexes were first calculated for each rotation and mean of the whole period was calculated as a next step. Also, descriptive statistics were used for the processing of the collected economic primary data (output price, various cost items). As a next step, the correlation between production parameters and average cost were analysed using correlation and regression analysis. Data processing was performed with Microsoft Excel and IBM SPSS Statistics 20.

\section{RESULTS AND DISCUSSION}

Production on the examined farm is carried out in 12 barns of $1000 \mathrm{~m}^{2}$ size each using a rotation system, i.e., the population is placed in a nursery barn $\left(1000 \mathrm{~m}^{2}\right)$ at a higher density and ducks are moved to three rearing barns in two weeks. This way, $4000 \mathrm{~m}^{2}$ useful barn surface is needed to rear a batch of duck. The barns were built around the 1970s and they are equipped with a modern automatic feeding and watering system using Chore Time technology. The heating of the buildings is performed with brooders and cross ventilation is used. The breed used at the farm was Cherry Valley, which has two types available on the market (Cherry Valley SM3 Medium and Cherry Valley SM3 Heavy). According to the data provided by the breeding company, Cherry Valley SM3 Medium is capable of reaching a slaughter weight of $3.45 \mathrm{~kg}$ 
in a 42-day-long rearing period in the case of $1.93 \mathrm{~kg} \mathrm{~kg}^{-1} \mathrm{FCR}$ and 2\% mortality rate, while Cherry Valley SM3 Heavy may reach $3.55 \mathrm{~kg}$ by the end of the 42-day-long rearing period with $1.88 \mathrm{~kg} \mathrm{~kg}^{-1} \mathrm{FCR}$ and $2 \%$ mortality rate (Cherry Valley, 2017). However, these performances can only be reached in exceptional cases under farming conditions. During the Hungarian performance analysis of the Cherry Valley SM3 Medium broiler duck in 2012 (Czinder and Meleg, 2012), $3.31 \mathrm{~kg}$ average weight, $2.16 \mathrm{~kg} \mathrm{~kg}^{-1} \mathrm{FCR}$ and $1.75 \%$ mortality rate were documented at densities of 8 ducks $\mathrm{m}^{-2}$ (nursery) and 4 ducks $\mathrm{m}^{-2}$ (rearing) in 42 days. In the case of the Super Heavy breed, the results of the 2016 experiments (Czinder and Meleg, 2016) were $3.67 \mathrm{~kg}$ average weight, $2.16 \mathrm{~kg} \mathrm{~kg}^{-1}$ FCR and $3.45 \%$ mortality rate at densities of 7.4 ducks $\mathrm{m}^{-2}$ (nursery) and 3.7 ducks $\mathrm{m}^{-2}$ (rearing) in 42 days.

Table 1 shows the specific cost and profit relations of the examined farm, averaged over the 96 production cycles between 2014-2016. The average cost of duck farming was 87.3 eurocent $\mathrm{kg}^{-1}$ in the given period, ranging between 72.6 eurocent $\mathrm{kg}^{-1}$ and 101.7 eurocent $\mathrm{kg}^{-1}$. The standard deviation of the index was 4.3 and the relative standard deviation was $5.0 \%$. Around $86-91 \%$ of production costs are provided by material costs, the most significant part of which is represented by feed (52-63\%) and day-old duckling (19-24\%) costs, which together represent more than $70 \%$ of all production costs. The cost of veterinary medicine is less significant, but it has a high relative standard deviation value $(64.1 \%)$. Similarly, the cost of litter also has a lower share (4\%), but its relative standard deviation is $26 \%$. The change of this value is greatly affected by ventilation and changes in weather, since rainy weather calls for the use of more litter. Personnel costs amount to $6-8 \%$ of production costs, while the share of depreciation is $2-3 \%$. The reason for the relatively low share of depreciation is the old and obsolete barn. Machinery and overhead costs (insurance and authority fees, management costs, etc.) are insignificant, typically ranging between $1-2 \%$.

The sales price of duck was between 98.4 and 112.9 eurocent $\mathrm{kg}^{-1}$ between 2014-2016, with the average sales price being 100.7 eurocent $\mathrm{kg}^{-1}$. The observed prices are in accordance with the trend of slaughter duck buying-in prices reported by HCSO (2017), but they are around 3 eurocent below that level. According to the Hungarian data, the buyingin price of slaughter duck dropped by nearly $14 \%$ between 2014 and 2016 and producers could sell duck to abattoirs/ processing plants at 103.9 eurocent $\mathrm{kg}^{-1}$ on average in the given period. Given the sales prices of the enterprise, the average profit of its activity was 13.5 eurocent $\mathrm{kg}^{-1}$, ranging between -3.3 and 25.7 eurocent $\mathrm{kg}^{-1}$ and the relative standard deviation of it was rather high (40.8\%). Altogether, as a result of decreasing prices, deteriorating profit was observed during the three examined years. Also, different profitability values were observed in each production cycle with an average ratio of $16 \%$, ranging between -3 and $35 \%$.

Based on the production cost per $\mathrm{m}^{2}$, it can be concluded that the average cost per $\mathrm{m}^{2}$ of rearing a production cycle at the farm is 11.9 EUR. The profit to be realised is between 13.3-18.2 EUR $\mathrm{m}^{-2}$, with the average value being 15.6 EUR $\mathrm{m}^{-2}$; therefore, the potential profit was between -0.5 and 4.1 EUR $\mathrm{m}^{-2}$.

Table 1. Cost and profit relations of broiler duck production (2014-2016; $n=96)$ Unit: eurocent $\mathrm{kg}^{-1}$

\begin{tabular}{|c|c|c|c|c|c|}
\hline Description & Mean & $\begin{array}{l}\text { Standard } \\
\text { deviation }\end{array}$ & $\begin{array}{c}\text { Relative } \\
\text { standard } \\
\text { deviation } \\
(\%) \\
\end{array}$ & Min. ${ }^{1}$ & Max. $^{1}$ \\
\hline Material costs & 77.3 & 4.1 & 5.4 & 62.8 & 89.5 \\
\hline Day-old duckling & 13.8 & 0.9 & 6.1 & 11.8 & 16.0 \\
\hline Feed & 50.5 & 3.5 & 6.9 & 38.0 & 59.2 \\
\hline Energy & 4.6 & 0.8 & 17.4 & 3.6 & 6.2 \\
\hline Litter & 3.6 & 0.9 & 26.0 & 1.3 & 8.7 \\
\hline Veterinary medicine & 0.6 & 0.4 & 64.1 & 0.2 & 2.2 \\
\hline Services $^{2}$ & 3.4 & 0.5 & 14.6 & 2.2 & 4.9 \\
\hline Other $^{3}$ & 0.8 & 0.1 & 16.2 & 0.5 & 1.1 \\
\hline Labour costs & 5.9 & 0.6 & 9.5 & 5.1 & 7.2 \\
\hline Depreciation & 1.9 & 0.1 & 6.7 & 1.7 & 2.4 \\
\hline Machinery costs & 1.3 & 0.7 & 53.7 & 0.3 & 2.1 \\
\hline Direct production costs & 86.5 & 4.3 & 5.0 & 72.0 & 100.9 \\
\hline Overheads & 0.8 & 0.2 & 28.3 & 0.5 & 1.8 \\
\hline Total production costs & 87.3 & 4.3 & 5.0 & 72.6 & 101.7 \\
\hline Sales price & 100.7 & 3.7 & 3.7 & 98.4 & 112.9 \\
\hline Profit & 13.5 & 5.5 & 40.8 & -3.3 & 25.7 \\
\hline $\begin{array}{l}\text { Cost-related } \\
\text { profitability }(\%)^{4}\end{array}$ & 15.7 & 6.7 & 42.7 & -3.2 & 35.4 \\
\hline
\end{tabular}

${ }^{I}$ Values shall not be summed up.

${ }^{2}$ animal health and animal husbandry services, waste disposal, transport, loading, other services etc.

${ }^{3}$ parts, repair and maintenance, work clothes, cleaning agents etc. ${ }^{4}$ profit/total production cost $\times 100$

\section{Source: own calculation}

Table 2 shows the main production parameters of the farm with reference to the examined period. The stocking density was between 19.2-24.3 ducklings per $\mathrm{m}^{2}$ during the nursery period. This value is more than twice as high as the experimental data published by Czinder and Meleg (2012) (8 ducklings per $\left.\mathrm{m}^{2}\right)$. The population moved to 
the rearing barn can only be estimated by calculating with $50 \%$ of the mortality rate of the whole fattening period. Accordingly, the density used during the rearing period was between 6.3-8.0 ducks per $\mathrm{m}^{2}$, with the average value being 6.6 ducks per $\mathrm{m}^{2}$. This value is $65 \%$ higher than the data reported by Czinder and Meleg (2012) (4 ducks per $\mathrm{m}^{2}$ ). The average mortality rate was $3.4 \%$ in the 96 rotations, which is nearly twice as high as the value obtained during the Hungarian farm performance analysis (Czinder and Meleg, 2012). Based on the analysis of the whole data series, it can be concluded that the sample range (5.4\%) and relative standard deviation of mortality (30.4\%) are high, which is due to the high stocking density and the shortcomings of the applied breeding technology and the resulting negative impacts of changing weather circumstances (e.g. summer heat). The final bodyweight was $3.09 \mathrm{~kg}$ per duck and the sample range of the index (0.85 kg per duck) was relatively high, but the relative standard deviation was low (5.2\%). The average weight on the farm was $0.22 \mathrm{~kg}(6.6 \%)$ lower than the experimental results (Czinder and Meleg, 2012). At the farm, the usual number of rearing days is 42 with a low relative standard deviation (5.7\%). The average daily weight gain expresses the two indexes and its value was $72.8 \mathrm{~g}$ per day, which is $6 \mathrm{~g}$ less than the value calculated from the data reported by Czinder and Meleg (2012) (78.8 g per day). FCR, which fundamentally affects average cost, was $2.24 \mathrm{~kg} \mathrm{~kg}^{-1}$ on average and the sample range of the index was $0.76 \mathrm{~kg}$ $\mathrm{kg}^{-1}$, while the relative standard deviation was $6.1 \%$. The farm FCR was only $0.08 \mathrm{~kg} \mathrm{~kg}^{-1}$ (3.7\%) higher than the values obtained as a result of the farm level performance analysis (Czinder and Meleg, 2012).

The efficiency of production can also be expressed as a complex index (EPEF), which includes both the mortality rate and the FCR, as well as the number of rearing days and the final bodyweight (Nabizadeh, 2012; Lückstäd, 2014; Szőllősi and Szűcs, 2014). This index is usually used in broiler chicken farming to compare the physical efficiency of different farms/barns/production cycle. However, since broiler duck production is similarly intensive as broiler chicken farming and it is performed using a closed technology, the index was adapted to duck farming. At the examined farm, the value of EPEF ranged between 245-382, with the average value being 316. Calculating from the production data published by $\mathrm{C}$

Czinder and Meleg (2012), the EPEF value was 358 which suggests that the physical efficiency of the examined farm is $12 \%$ less favourable. However, this index does not include the intensity of the barn (sold live weight per $\mathrm{m}^{2}$ as a result of stocking density) which reduces average cost through average fixed costs. On average, the examined farm produces $15.5 \mathrm{~kg}$ live weight on one $\mathrm{m}^{2}$, which is $2.5 \mathrm{~kg}(19 \%)$ higher than the value calculated from experimental data (Czinder and Meleg, 2012).
Table 2. Production indexes of broiler duck production $(n=96)$

\begin{tabular}{|c|c|c|c|c|c|c|}
\hline 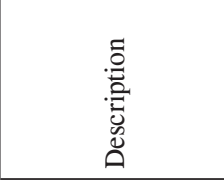 & 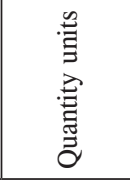 & $\stackrel{\mathrm{E}}{\Sigma}^{\bar{E}}$ & 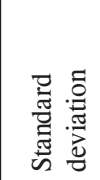 & 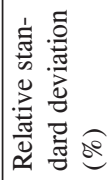 & $\dot{\Sigma}$ & $\sum_{\Sigma}^{\dot{\varpi}}$ \\
\hline $\begin{array}{l}\text { Stocking density - } \\
\text { nursery }^{1}\end{array}$ & $\begin{array}{l}\text { ducklings } \\
\text { per } \mathrm{m}^{2}\end{array}$ & 20.8 & 0.9 & 4.4 & 19.2 & 24.3 \\
\hline $\begin{array}{l}\text { Stocking density - } \\
\text { rearing }{ }^{2}\end{array}$ & $\begin{array}{l}\text { ducks per } \\
\mathrm{m}^{2}\end{array}$ & 6.6 & 0.3 & 4.5 & 6.3 & 8.0 \\
\hline Rearing period & days & 42.4 & 2.4 & 5.7 & 37.0 & 49.0 \\
\hline Final bodyweight & $\begin{array}{l}\text { kg per } \\
\text { duck }\end{array}$ & 3.1 & 0.2 & 5.2 & 2.7 & 3.6 \\
\hline $\begin{array}{l}\text { Average daily } \\
\text { weight gain }\end{array}$ & g per day & 72.8 & 4.2 & 5.7 & 61.3 & 82.5 \\
\hline $\begin{array}{l}\text { Feed Conversion } \\
\text { Ratio }\end{array}$ & $\mathrm{kg}$ per $\mathrm{kg}$ & 2.2 & 0.1 & 6.1 & 2.0 & 2.8 \\
\hline Mortality rate & $\%$ & 3.4 & 1.0 & 30.4 & 1.5 & 6.9 \\
\hline Sold live weight ${ }^{3}$ & $\mathrm{~kg}$ per $\mathrm{m}^{2}$ & 15.5 & 1.1 & 7.2 & 13.1 & 18.5 \\
\hline EPEF $^{4}$ & - & 315.9 & 29.8 & 9.4 & 245.1 & 382.4 \\
\hline
\end{tabular}

${ }^{1}$ Nursing is performed on a barn size of $1000 \mathrm{~m}^{2}$.

${ }^{2}$ Rearing is performed on a barn size of $3000 \mathrm{~m}^{2}$. This index is an estimated value based on the assumption that the mortality rate during nursing is $50 \%$ of the total mortality rate.

${ }^{3}$ Projection base is $4000 \mathrm{~m}^{2}$ in the case of sold live weight (nursery and rearing barns).

${ }^{4} E P E F=((100-$ mortality rate $) \times$ final bodyweight $) /(F C R \times$ number of rearing days) $\times 100$

\section{Source: own calculation}

The distribution of each index was shown on histograms by supplementing the calculated statistical data. The number of rearing days was 42 in $26 \%$ of production cycles and 43 in $20 \%$ of production cycles (Figure 1). The distribution of mortality rate is shown in Figure 2, which leads to the conclusion that mortality rate was between $2-4 \%$ in $78 \%$ of cases. During the examined period, extremely high mortality above $6 \%$ was observed in four cases (4\%). The establishment of these production cycles was usually performed in the summer, which is the reason for the high mortality rate. FCR was between $2.1-2.3 \mathrm{~kg} \mathrm{~kg}^{-1}$ in $63 \%$ of cases. The maximum FCR value was $2.8 \mathrm{~kg} \mathrm{~kg}^{-1}$ which was observed in only one case (Figure 3). The final bodyweight was between 3-3.1 $\mathrm{kg}$ per duck most frequently, which represents $35 \%$ of the examined production cycles, while ducks were fattened to $3.1-3.2 \mathrm{~kg}$ in $21 \%$ of cases (Figure 4). Figure 5 shows that EPEF ranged between 301-340 in 52\% of production cycles, while average cost was between $85-90$ eurocent $\mathrm{kg}^{-1}$ in $49 \%$ of cases (Figure 6). 
Figure 1. Share of rearing period $(n=96)$ Source: own calculation

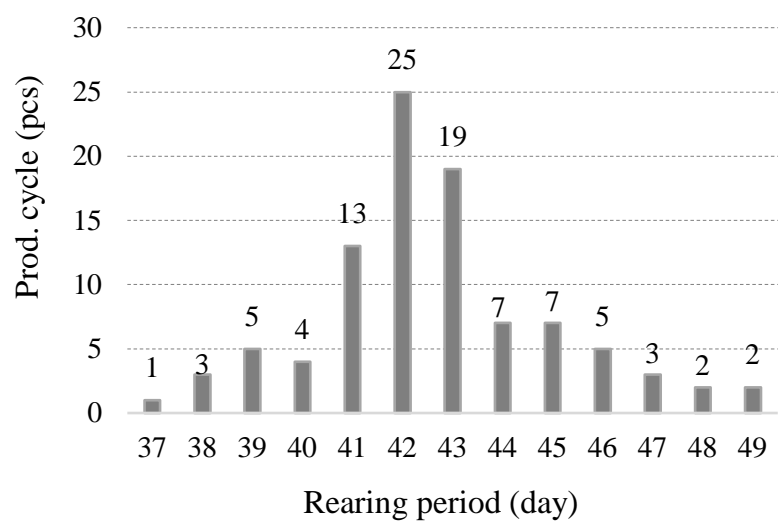

Figure 3. Share of FCR value $(n=96)$ Source: own calculation

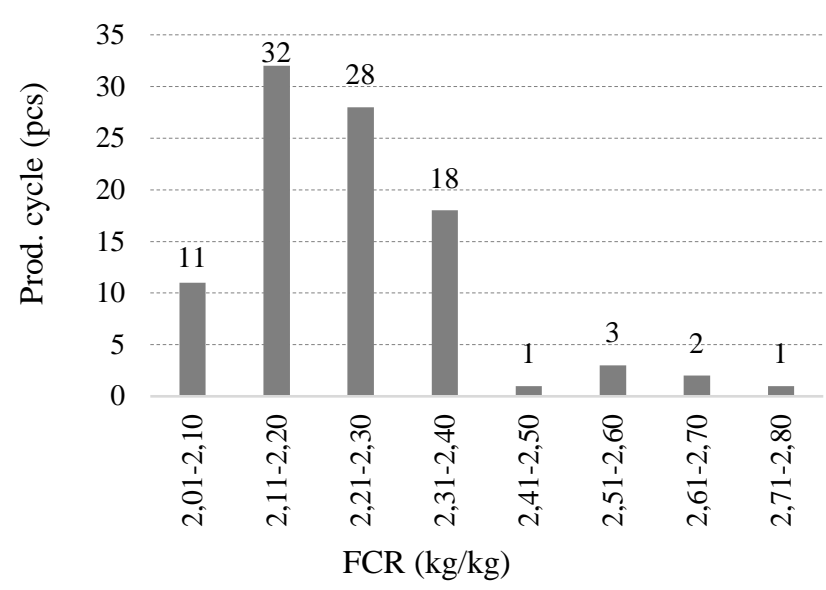

Figure 5. Share of EPEF value $(n=96)$ Source: own calculation

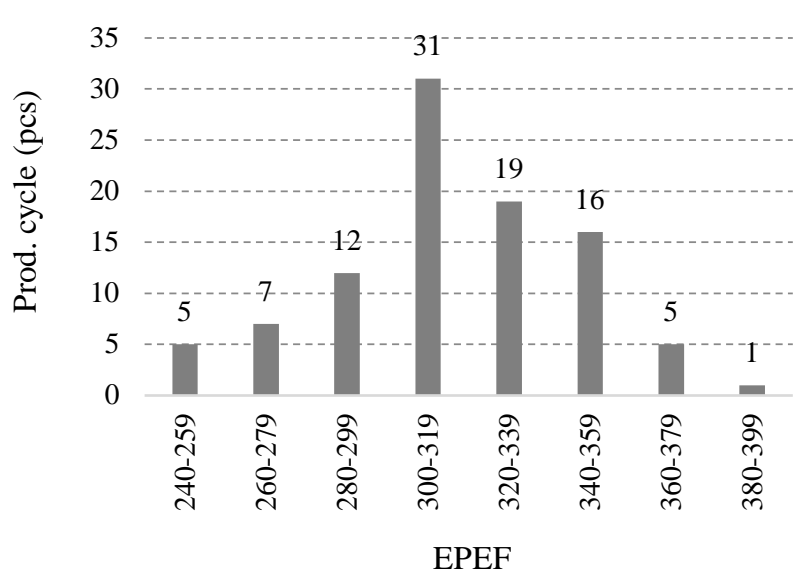

Figure 2. Share of mortality rate $(n=96)$ Source: own calculation

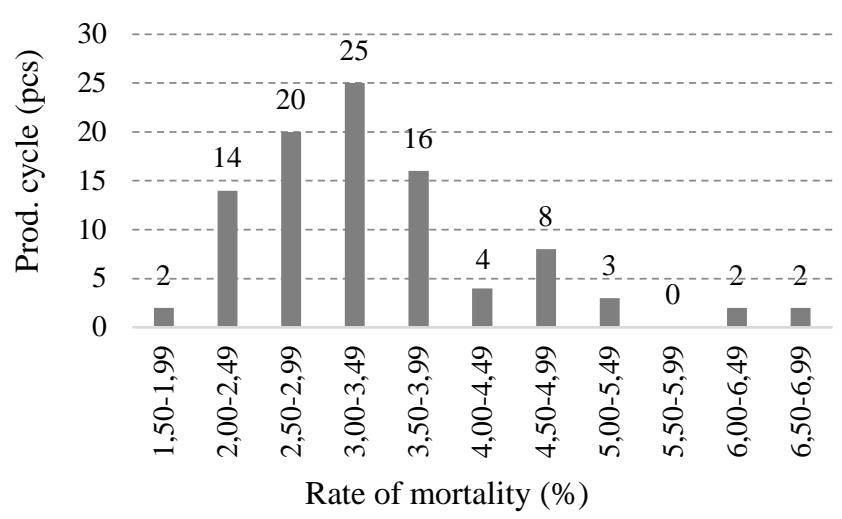

Figure 4. Share of final bodyweight $(n=96)$ Source: own calculation

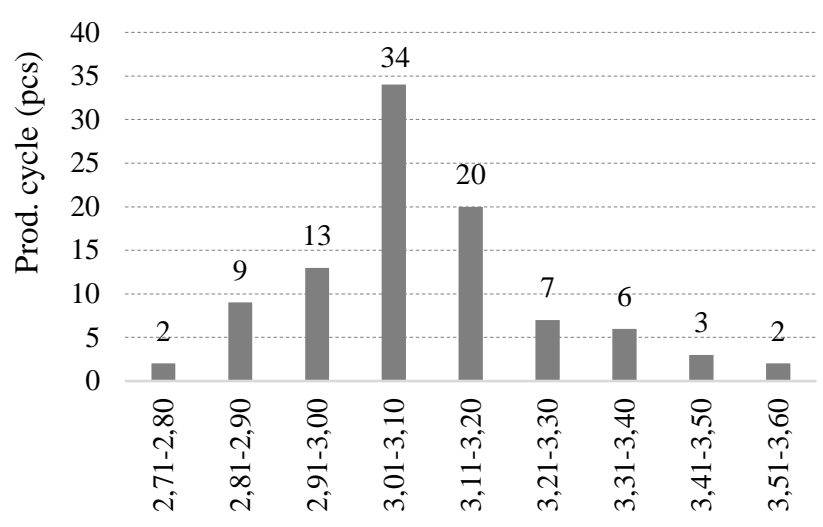

Final bodyweight (kg/pcs)

Figure 6. Share of average cost $(n=96)$ Source: own calculation

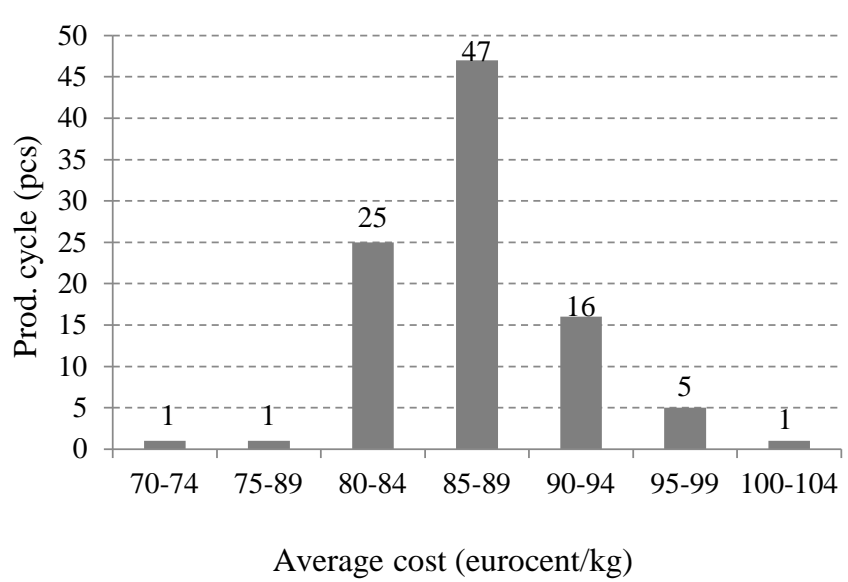


Table 3. Results of correlation and regression analysis $(n=96)$

\begin{tabular}{|c|c|c|c|c|c|c|}
\hline $\begin{array}{c}\text { Dependent } \\
\text { variable }\end{array}$ & $\begin{array}{c}\text { Independent } \\
\text { variable }(\mathrm{x})\end{array}$ & $\mathrm{R}$ & $\mathrm{R}^{2}$ & F & $\mathrm{p}$ & Constant \\
\hline $\begin{array}{l}\text { Average } \\
\text { cost } \\
\text { (eurocent } \\
\mathrm{kg}^{-1} \text { ) }\end{array}$ & $\begin{array}{l}\text { Final } \\
\text { bodyweight } \\
\text { (kg per } \\
\text { duck) }\end{array}$ & 0.227 & 0.051 & 5.092 & 0.026 & 106.207 \\
\hline $\begin{array}{l}\text { Average } \\
\text { cost } \\
\text { (eurocent } \\
\mathrm{kg}^{-1} \text { ) }\end{array}$ & $\begin{array}{l}\text { Rearing } \\
\text { period } \\
\text { (days) }\end{array}$ & 0.469 & 0.220 & 26.538 & 0.000 & 51.667 \\
\hline $\begin{array}{l}\text { Average } \\
\text { cost } \\
\text { (eurocent } \\
\mathrm{kg}^{-1} \text { ) }\end{array}$ & \begin{tabular}{|l} 
Daily \\
weight gain \\
(g per day)
\end{tabular} & 0.657 & 0.431 & 71.332 & 0.000 & 136.838 \\
\hline $\begin{array}{l}\text { Average } \\
\text { cost } \\
\text { (eurocent } \\
\mathrm{kg}^{-1} \text { ) }\end{array}$ & $\begin{array}{l}\text { Mortality } \\
(\%)\end{array}$ & 0.521 & 0.271 & 34.969 & 0.000 & 79.856 \\
\hline $\begin{array}{l}\text { Average } \\
\text { cost } \\
\text { (eurocent } \\
\mathrm{kg}^{-1} \text { ) }\end{array}$ & $\begin{array}{l}\text { FCR }(\mathrm{kg} \\
\left.\mathrm{kg}^{-1}\right)\end{array}$ & 0.668 & 0.446 & 75.722 & 0.000 & 39.555 \\
\hline $\begin{array}{l}\text { Average } \\
\text { cost } \\
\text { (eurocent } \\
\mathrm{kg}^{-1} \text { ) }\end{array}$ & EPEF & 0.861 & 0.742 & 270.144 & 0.000 & 126.856 \\
\hline $\begin{array}{l}\text { Average } \\
\text { cost } \\
\text { (eurocent } \\
\mathrm{kg}^{-1} \text { ) }\end{array}$ & $\begin{array}{l}\text { Sold live } \\
\text { weight } \\
\left(\mathrm{kg} \mathrm{m}^{-2}\right)\end{array}$ & 0.332 & 0.110 & 11.624 & 0.001 & 107.394 \\
\hline $\begin{array}{l}\text { Sold live } \\
\text { weight } \\
\left(\mathrm{kg} \mathrm{m}^{-2}\right)\end{array}$ & $\begin{array}{l}\text { Feed use } \\
\left(\mathrm{kg} \mathrm{m}^{-2}\right)\end{array}$ & 0.780 & 0.608 & 145.756 & 0.000 & 6.597 \\
\hline $\begin{array}{l}\text { Final } \\
\text { bodyweight } \\
\text { (kg per } \\
\text { duck) }\end{array}$ & $\begin{array}{l}\text { Feed use } \\
\text { (kg per } \\
\text { duck) }\end{array}$ & 0.750 & 0.562 & 120.492 & 0.000 & 1.728 \\
\hline
\end{tabular}

Source: own calculation

As a next step, correlation and regression analysis was carried out to examine the correlation between production parameters and average cost (Table 3). Based on the obtained results, there is a weak ${ }^{1}$ correlation $(\mathrm{R}=0.227, \mathrm{p}<0.05)$ between average cost and final bodyweight and the $0.1 \mathrm{~kg}$ increase of bodyweight results in 6.131 eurocent reduction $(y=-6.131 x+106.207)$ of average cost. However, the linear model explains only $5 \%$ of average cost $\left(\mathrm{R}^{2}=0.051\right)$. On the contrary, moderate correlation $(\mathrm{p}<0.05)$ can be observed if average cost is compared to the number of rearing days, daily weight gain, mortality rate and FCR. Based on the obtained results, it can be concluded that one extra rearing day increases average cost by 0.839 eurocent $(y=0.839 x+51.667)$, whole 1 $\mathrm{g}$ of extra daily weight gain decreases average cost by 0.68

1 Based on Pearson's coefficient of correlation, the following target values were used to determine the closeness of correlations: weak: $0.0-0.4$, moderate: $0.4-0.7$, strong: $0.7-0.9$, very strong: above 0.9 (Sváb 1967 cit. Mészáros 1981). eurocent $(y=-0.68 x+136.838) .1 \%$-point increase of mortality increases average cost by 2.169 eurocent $(y=2.169 x+79.856)$, while the $0.1 \mathrm{~kg}$ deterioration of FCR increases average cost by 2.13 eurocent $(y=21.347 x+39.555)$. The regression models to be used explain $22 \%$ of average cost in relation to rearing days, $43 \%$ in relation to daily weight gain, $27 \%$ concerning mortality rate and $45 \%$ with reference to feed conversion ratio.

In addition, based on the obtained findings, it can be emphasised that the EPEF, which is used as an expression of the physical efficiency of broiler chicken production with a complex index, can be adapted to the duck sector, since there is a strong positive correlation between the index and the average cost of production $(\mathrm{R}=0.861, \mathrm{p}<0.05)$ which is scientifically verified. Based on the linear regression model $(y=-0.125 x+126.856)$ - which explains $74 \%$ of average cost $\left(\mathrm{R}^{2}=0.742\right)$ - it can be concluded that a 10 -unit improvement of the EPEF value results in a 1.25 eurocent reduction of average cost.

The correlation between the amount of live weight sold per $1 \mathrm{~m}^{2}$ and the amount of feed used per $\mathrm{m}^{2}$ is strong $(\mathrm{R}=0.780$, $\mathrm{p}<0.05)$ and the linear regression model $(y=0.256 x+6.597)$ explains $61 \%$ of the dependent variable. One extra $\mathrm{kg}$ feed use per $\mathrm{m}^{2}$ increases the produced live weight per $\mathrm{m}^{2}$ by $0.256 \mathrm{~kg}$. Also, a close positive correlation was observed between the final bodyweight and total amount of feed used to rear a duck $(\mathrm{R}=0.750)$. The linear regression model $(y=0.197 x+1.728)$ explains $56 \%$ of the sold live weight per $1 \mathrm{~m}^{2}$. On the contrary, there is a weak correlation $(\mathrm{R}=0.332, \mathrm{p}<0.05)$ between average cost and the sold live weight per $1 \mathrm{~m}^{2}$ and the respective regression model $(y=-1.300 x+107.394)$ explains only $11 \%$ of average cost. 1 $\mathrm{kg}$ increase of the sold live weight per $1 \mathrm{~m}^{2}$ results in 1.3 eurocent reduction of average cost.

Table 4. Multivariate linear regression models (n=96)
\begin{tabular}{|c|l|c|c|c|}
\hline Model & \multicolumn{1}{|c|}{ Predictors } & $\mathrm{R}$ & $\mathrm{R}^{2}$ & $\mathrm{p}$ \\
\hline 1 & $\mathrm{x}_{1}:$ FCR $\left(\mathrm{kg} \mathrm{kg}^{-1}\right)$ & 0.668 & 0.446 & 0.00 \\
\hline 2 & $\begin{array}{l}\mathrm{x}_{1}: \text { FCR }\left(\mathrm{kg} \mathrm{kg}^{-1}\right) \\
\mathrm{x}_{2}: \text { Mortality }(\%)\end{array}$ & 0.836 & 0.699 & 0.00 \\
\hline 3 & $\begin{array}{l}\mathrm{x}_{1}: \text { FCR }\left(\mathrm{kg} \mathrm{kg}^{-1}\right) \\
\mathrm{x}_{2}: \text { Mortality }(\%)\end{array}$ \\
$\begin{array}{l}\mathrm{x}_{3}: \text { Final bodyweight }(\mathrm{kg} \\
\text { per duck) }\end{array}$ & 0.881 & 0.776 & 0.00 \\
\hline 4 & $\begin{array}{l}\mathrm{x}_{1}: \text { FCR (kg kg-1) } \\
\mathrm{x}_{2}: \text { Mortality (\%) } \\
\mathrm{x}_{3}: \text { Final bodyweight (kg } \\
\text { per duck) } \\
\mathrm{x}_{4}: \text { Rearing period (days) }\end{array}$ & 0.906 & 0.820 & 0.00 \\
\hline
\end{tabular}

Dependent variable (y): Average cost (eurocent $\mathrm{kg}^{-1}$ ) Source: own calculation

The correlation between several factors at the same time (FCR, mortality rate, final bodyweight and rearing period) and average cost was observed with a multivariate linear regression 
models applied stepwise method (Table 4). It was concluded that the correlation between these factors is very strong $(\mathrm{R}=0.906$, $\mathrm{p}<0.05)$. The multivariate linear regression model can be described as

$$
\mathrm{y}=20.033 \mathrm{x}_{1}+1.425 \mathrm{x}_{2}-11.149 \mathrm{x}_{3}+0.494 \mathrm{x}_{4}+51.032
$$

where $\mathrm{x}_{1}$ : FCR, $\mathrm{x}_{2}$ : mortality rate, $\mathrm{x}_{3}$ : final bodyweight and $\mathrm{x}_{4}$ : rearing period and it explains $82 \%$ of average cost $\left(\mathrm{R}^{2}=0.820\right)$.

\section{CONCLUSIONS}

As a result of research, it can be concluded that the largest proportion of the production cost of broiler duck is material cost, which is determined by the cost of feed and day-old duckling. The average cost of broiler duck production of the examined enterprise was between 72.6-101.7 eurocent $\mathrm{kg}^{-1}$ in the period between 2014-2016, with the average being 87.3 eurocent $\mathrm{kg}^{-1}$. Sales prices were mostly higher than production costs and production was profitable on average (16\%), however, profitability decreased. Depending on the technological level of the examined farm, broiler duck production is suitable for reaching 3.0-3.2 $\mathrm{kg}$ average weight during 42 days of life, while FCR is $2.1-2.3 \mathrm{~kg} \mathrm{~kg}^{-1}$ and mortality rate is between $2-4 \%$, while the stocking density was 6.6 ducks per $\mathrm{m}^{2}$ during the rearing period. Based on the examination of the correlation between the various production parameters and average cost, it can be concluded that there is a weak correlation between average cost and final bodyweight, as well as between average cost and sold live weight per $\mathrm{m}^{2}$. Moderate correlation was found between average cost and the rearing period, daily weight gain, mortality and FCR. In addition, there was a close correlation between average cost, EPEF, sold live weight per $\mathrm{m}^{2}$ and the amount of feed used per $\mathrm{m}^{2}$, as well as the final bodyweight and the amount of feed needed to rear a duck. A very strong correlation was observed between average cost and final bodyweight, FCR, mortality rate and rearing period at the same time. Furthermore, it was concluded that EPEF, which is widely used in evaluating the efficiency of slaughter chicken rearing, can be adapted also to broiler duck production, since there is a strong positive correlation between average cost and this index. The correlations presented in this study will be used in preparing the economic simulation model of broiler duck production which is planned to be the next step of research work.

\section{REFERENCES}

AVAR L. (2015): Jobb a kacsa, mint a liba. Magyar Mezőgazdaság 70, 14-15.

AVEC (2016): Annual Report 2016. 52 p. Available at: http://www. avec-poultry.eu/annual-reports-overview/annual-report-2016.

BÁBÁNÉ DEMETER E. (ed.) (2017): Statisztikai jelentések - Vágóhidak élóállat-vágása. 10(2), Agrárgazdasági Kutató Intézet, Budapest, 12. Available at: https://www.aki.gov.hu/publikaciok/dokumentum/f:96 702/2017.+IIII.+h\%C3\%B3+(2017.+2.+sz\%C3\%A1m).

BOGENFÜRST F. (2008): A víziszárnyas ágazat helyzete és jövőbeni kilátásai Magyarországon. Állattenyésztés és takarmányozás 57(5), 403-414.
CHERRY VALLEY (2017): Cherry Valley SM3 Product Specification. Cherry Valley Farms Ltd. Available at: http://www.cherryvalley.co.uk/ enquiriesandspecifications.

CZINDER K., MELEG I. (2012): Cherry Valley SM3 Medium pecsenyekacsa üzemi teljesítményvizsgálatának eredményei 2012. 20 p. Available at: http://portal.nebih.gov.hu/documents/10182/45539/ Zarojelentes_Cherry_Valley_SM3_Medium_2013.01.28._veglegesdoc.pdf/4a900668-bef̄1-43b8-9192-6856b346f0̄30.

CZINDER K., MELEG I. (2016): Cherry Valley SM3 Super Heavy pecsenyekacsa üzemi teljesítményvizsgálatának eredményei 2016. 18 p. Available at: http://portal.nebih.gov.hu/documents/10182/43858/Cherry + Valley+SM3 +Super+Heavy+pecsenyekacsa $+\% \mathrm{C} 3 \% \mathrm{BCzemi}+$ teljes \%C3\%ADtm\%C3\%A9nyvizsg\%C3\%A1lat\%C3\%A1nak+eredm\%C3\% A9nyei+-2016..pdf/f8624e2e-2c9a-457f-a2b7-ac4dd964ebe4.

COMTRADE (2017): UN Comtrade Database, Available at: http://comtrade.un.org/.

CSORBAI A. (2015): A magyar baromfiipar és az ágazatok helyzete, lehetőségei, versenyképessége, avagy előre vagy hátra? Baromfi Hírmondó - Az Agrofeed Kft. baromfi hírlevele 22(3), 5-7.

DUNN N. (2008): Wisenhof's single-source secret to success. Poultry International 47, 10-13.

FAO (2017): Food and Agroculture Organization of the United Nations' database. Available at: http://www.fao.org/statistics/en/.

HCSO (2017): Statisztikai tükör, 2017.03.06. Állatállomány, 2016.12.01. Hungarian Central Statistical Office. 4 p. Available at: https://www.ksh. hu/docs/hun/xftp/idoszaki/allat/allat1612.pdf.

HNB (2017): Hungarian National Bank: Exchange rates. Available at: http://www.mnb.hu/arfolyam-lekerdezes.

KÁLLAY B. (2014): Kacsatermelési integráció Mélykúton. Baromfiágazat 14(1), 54-57.

KOZÁK J., SZÁSZ S. (2016): Mai irányok a víziszárnyas-tenyésztésben. Állattenyésztés és Takarmányozás 65(4), 47-73.

LÜCKSTAD C (2014): A strategic approach to salmonella control in poultry. International Hatchery Practice 24(5), 15-17.

MÉSZÁROS S. (1981): Összefüggés-vizsgálatok. In: Alapismeretek az operációkutatáshoz (ed.: CSÁKI CS., MÉSZÁROS S.). Mezőgazdasági Kiadó. Budapest. 42.

MOLNÁR GY., LÁTITS M. (2016): A lúd ágazat eredményei és aktuális feladatai. Baromfi Termék Tanács. XVIII. Kiskunfélegyházi Libafesztivál - Szakmai Konferencia. 2016. szeptember 9.

NABIZADEH A. (2012): The effect of inulin on broiler chicken intestinal microflora, gut morphology, and performance. J. Animal and Feed Sciences 21, 725-734. https://doi.org/10.22358/jafs/66144/2012

RAE A. (2014): Successful duck breeding - progress through technology. International Hatchery Practice 28(6), 6-9.

SZŐLLŐSI L., SZŰCS I. (2014): An economic approach to broiler production: a case study from Hungary. Annals of the Polish Association of Agricultural and Agribusiness Economists 16(3), 275-281.

SVÁB J. (1967): Biometriai módszerek a mezőgazdasági kutatásban. Mezőgazdasági Kiadó. Budapest.

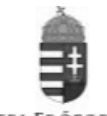
EMBERI ERÓFORRÁSOK MINISZTÉRIUMA 
